\title{
High-resolution dust modelling over complex terrains in West Asia
}

\author{
S. Basart ${ }^{1}$, L. Vendrell $^{1}$ and J.M. Baldasano ${ }^{1,2}$
}

[1] Barcelona Supercomputing Center-Centro Nacional de Supercomputación, Barcelona, Spain

[2] Environmental Modelling Laboratory, Technical University of Catalonia, Barcelona, Spain 


\title{
High-resolution dust modelling over complex terrains in West Asia
}

\begin{abstract}
The present work demonstrates the impact of model resolution in dust propagation in a complex terrain region such as West Asia. For this purpose, two simulations using the NMMB/BSC-Dust model are performed and analysed, one with a high horizontal resolution (at $0.03^{\circ} \times 0.03^{\circ}$ ) and one with a lower horizontal resolution (at $0.33^{\circ} \mathrm{x}$ $0.33^{\circ}$ ). Both model experiments cover two intense dust storms that occurred on 17-20 March 2012 as a consequence of strong northwesterly Shamal winds that spanned over thousands of kilometres in West Asia. The comparison with ground-based (surface weather stations and suphotometers) and satellite aerosol observations (Aqua/MODIS and MSG/SEVIRI) shows that despite differences in the magnitude of the simulated dust concentrations, the model is able to reproduce these two dust outbreaks. Differences between both simulations on the dust spread rise on regional dust transport areas in south-western Saudi Arabia, Yemen and Oman. The complex orography in south-western Saudi Arabia, Yemen and Oman (with peaks higher than $3000 \mathrm{~m}$ ) has an impact on the transport dust concentration fields over mountain regions. Differences between both model configurations are mainly associated to the channelization of the dust flow through valleys and the differences on the modelled altitude of the mountains that alters the meteorology and blocks the dust fronts limiting the dust transport. These results demonstrate how the dust prediction in the vicinity of complex terrains improves using high-horizontal resolution simulations.
\end{abstract}

Keywords: dust modelling, dust transport, Shamal, satellite aerosol products, topography, NMMB/BSC-Dust

\section{Introduction}

Mineral dust represents the major contribution to atmospheric optical thickness in many regions (Tegen et al., 1997), and evidence exists of increasing dust production in recent decades (Prospero and Lamb, 2003; Mahowald et al., 2010). Dust storms play an important role in the Earth system with important impacts on radiation (IPCC, 2013), clouds (Karyampudi and Pierce, 2002), atmospheric chemistry (Prospero et al., 1995; Cuevas et al., 2013), ecosystems (Fung et al., 2000; Jickells and Spokes, 2001; Mahowald et al., 2005; UNEP, 2012), biogeochemical cycles (Jickells et al., 2005; Schulz et al., 2012), human health issues such as respiratory diseases, cardiovascular diseases, infections (Thomson et al., 2006; Díaz et al., 2012; De Longueville et al., 
2013; Pérez García-Pando et al., 2014), and also on ground and air transportation due to visibility reduction (Shirkhani-Ardehjani, 2012), energy and industry (El-Nashar, 2003; Elminir et al., 2006; Ohde and Siegel, 2012; Kazem et al., 2014) and satellite retrievals (Merchant et al., 2006; Amiridis et al., 2013). Modelling is essential not only to have a powerful tool to predict the global or regional dust budget and its interaction in the climate-weather system, but also to complement remote sensing and in-situ observations and to understand dust processes.

In the recent years, a number of dust models have been developed for regional and global dust prediction such as global models like the Navy Aerosol Analysis and Prediction System (NAAPS; Westphal et al., 2009), the Met Office Unified Model (MetUM ${ }^{\mathrm{TM}}$; Woodward, 2011; Collins et al., 2011), the aerosol model at the European Centre for Medium-range Weather Forecasts (MACC-ECMWF; Morcrette et al., 2009; Benedetti et al., 2009) and NMMB/BSC-Dust (Pérez et al., 2011; Haustein et al., 2012). The above global models, together with others, are participating in the International Cooperative for Aerosol Prediction (ICAP) Initiative (Sessions et al., 2015) for aerosol forecast centres, remote sensing data providers, and to lead systems developers to share best practices and to discuss pressing issues facing the operational aerosol community. There are also several regional models that have been developed to predict the dust cycle, for example the BSC-DREAM8b model (Nickovic et al., 2001; Pérez et al., 2006a,b; Basart et al., 2012) and the CHIMERE model (Menut, 2008; Schmechtig et al., 2011). The models mentioned above (global and regional) are participating in the World Meteorological Organization (WMO) Sand and Dust Storm Warning Advisory and Assessment System Northern Africa, Middle East and Europe Regional Center (SDSWAS NAMEE RC; http://sdswas.aemet.es/). The NAMEE RC seeks to achieve comprehensive, coordinated and sustained observations and modelling capabilities of sand and dust storms, in order to improve their monitoring state, increase the understanding of their formation processes, and enhance prediction capabilities of dust models. The studies comparing and evaluating the temporal (on annual, seasonal and daily basis) and spatial variability of desert dust load and deposition simulated by different models contribute to determine the limitations of the current models and the degree of uncertainty in estimates of dust emission, transport and deposition. They also highlight the sources of uncertainty in these estimates, and point to the key foci for future research to constrain these uncertainties. West Asia is one of the regions where the participating models in the WMO SDS-WAS NAMEE RC shows high variability (Terradellas et al., 2012). Miller et al. (2004) and Tanaka and Chiba (2006) suggest that about $15-20 \%$ of the global dust emission is from the Arabian Peninsula and Central Asia. The alluvial plains and dry deserts in southwestern Asia and in West Asia are important dust sources associated with a complex topography (Ginoux et al., 2012). Topography alters the meteorology of dust emission and transport in many ways. Liu and Westphal (2001) show that wind and dust simulations improve over Asia due to a better-resolved topography. Israelevich et al. (2012) observe an accumulation of desert dust in the Po Valley in front of Alps as the dust-carrying air flow from North Africa 
reaches them and slows down, highlighting that the terrain relief may also affect aerosol propagation.

The NMMB/BSC-Dust model has been selected as the operational model of the first WMO Regional Meteorological Center specialized in Atmospheric Sand and Dust Forecast, the Barcelona Dust Forecast Center (BDFC; http://dust.aemet.es). The present work investigates the NMMB/BSC-Dust model's ability to reproduce dust propagation in complex terrains. For this purpose, two simulations are performed, one with a high horizontal resolution (at $0.03^{\circ} \times 0.03^{\circ}$ ) and one with a lower horizontal resolution (at $0.33^{\circ} \times 0.33^{\circ}$ ), both of which covered two intense dust storms that occurred on 17-20 March 2012 that spanned over thousands of kilometres affecting the whole Arabian Peninsula. The model results are compared against ground-based (AERONET and weather stations) observations and satellite aerosol products (Aqua/MODIS and MSG/SEVIRI). Section 2 includes a geographical description of the study region, West Asia. In Sect. 3, the NMMB/BSC-Dust model and descriptions of the different observational datasets are introduced. Sect. 4 reports an overview of the entire dust event in mid-March 2012, the model evaluation and the discussion of the corresponding results. Finally, Sect. 5 concludes the present analysis.

\section{Study region: West Asia}

West Asia is a singular region characterized by a complex topography (with several peaks higher than $3000 \mathrm{~m}$ ); a low average annual precipitation; low soil moisture content; small dust sources with erodible sediments of fine particles from areas with dry lakebeds, dry riverbeds and sand seas; and a wide variety of meteorological phenomena (e.g., Shamal winds, thermal sea breezes, thunderstorms or low level jets) which are able to produce severe dust storms (i.e., Rezazadeh et al., 2013). Its three primary desert regions are the Rub Al-Khali ("Empty Quarter") in the southeast, An Nafud in the northwest, and the Ad Dahna sand corridor in the east, connecting the previous two deserts. Remote desert regions that can potentially serve as dust source regions to Saudi Arabia include the vast Saharan Desert to the west and Syrian and Iraqi Deserts to the north (Prospero, 2002; Goudie and Middleton, 2006). The seasonal variation of the dust activity in the West Asia is complex and differs for different regions. In most parts of West Asia, dust is active all year long, with minimum activity in the winter months. Dust activity increases in March and April, peaks in June and July and weakens in September (Shao, 2008).

West Asia contains large areas of mountainous terrain (Figure 1). The Zagros Mountains are located in Iran, in areas along its border with Iraq. The Central Plateau of Iran is divided into two drainage basins: the northern basin is Dasht-e-Kavir (Great Salt Desert), and is the southern basin is Dasht-e-Lut. In Yemen, elevations exceed $3000 \mathrm{~m}$ in many areas, and highland areas extend north along the Red Sea coast and north into Lebanon. A fault-zone also exists along the Red Sea, with continental rifting creating trough-like topography with areas located well-below sea level. Al-Hajar 
mountain range is located in the east of the United Arab Emirates (UAE) and along the
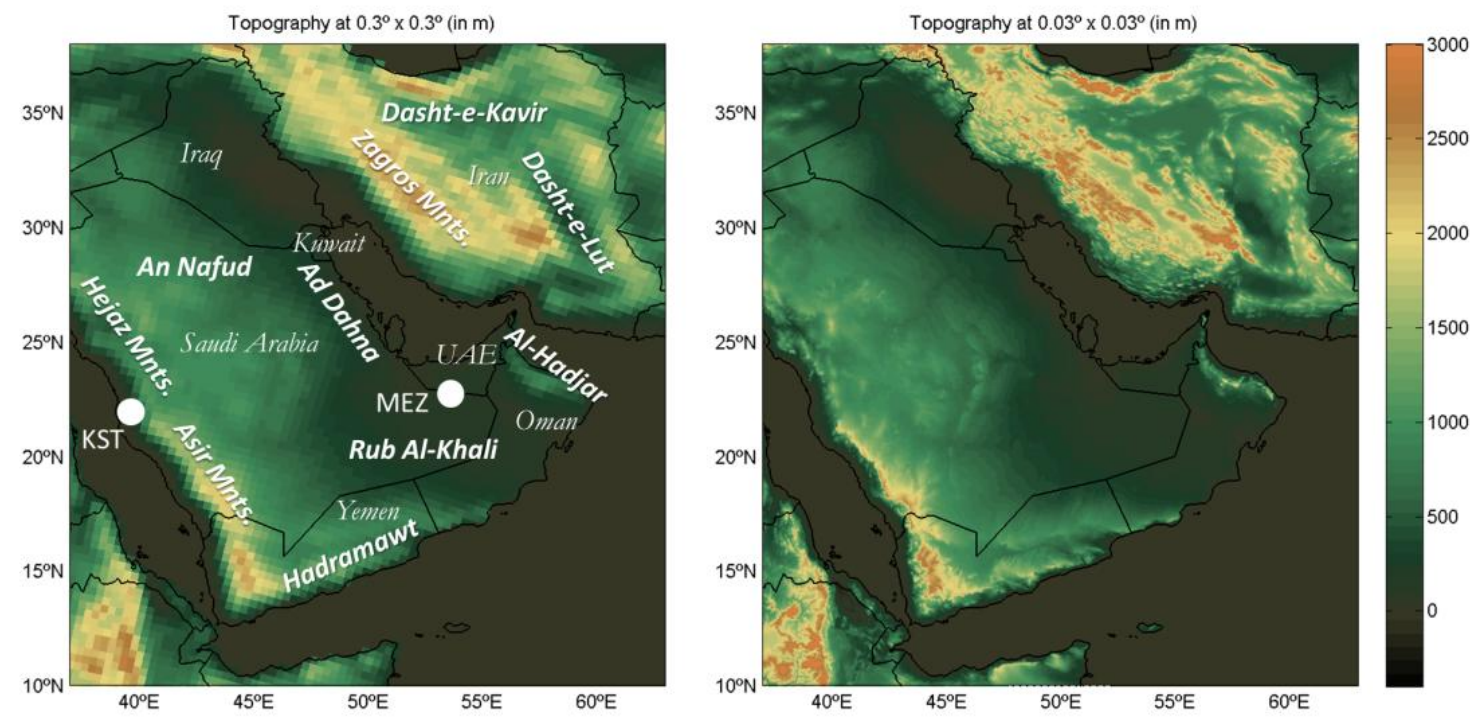

Figure 1. Interpolated topography at $0.33^{\circ} \times 0.33^{\circ}$ and $0.03^{\circ} \times 0.03^{\circ}$ horizontal resolutions over the study region in the colour scale. The main countries referred in the text (Oman, Yemen, Saudi Arabia, Kuwait, Iran, Iraq and UAE), primary desert dust regions (Rub Al-Khali, Ad Dahna and An Nafud in Arabian Peninsula; and Dasht-e-Kavir and Dasht-e-Lut in Iran), main mountains referred in the text (Hadramawt, Asir, Hejaz, Al-Hadjar and Zagros Mountains) and the two AERONET sites used in the study (i.e., Kaust Campus, KST, and Mezaira, MEZ) are indicated in the map.

\section{Methods}

\subsection{The NMMB/BSC-Dust model}

The NMMB/BSC-Dust model (Pérez et al., 2011; Haustein et al., 2012) is the dust module of the NMMB/BSC-Chemical Transport Model (NMMB/BSC-CTM; Pérez et al., 2011; Jorba et al., 2012; Spada et al., 2013; Badia and Jorba, 2014; https://www.bsc.es/earth-sciences/nmmbbsc-project). The NMMB/BSC-Dust has been developed at the Earth Sciences Department of the Barcelona Supercomputing CenterCentro Nacional de Supercomputación (BSC) in collaboration with NOAA/National Centers for Environmental Prediction (NCEP), NASA Goddard Institute for Space Studies and the International Research Institute for Climate and Society (IRI). The NMMB/BSC-Dust model provides operational dust forecast over North Africa-Middle East-Europe and global regions.

The most relevant characteristic of the NMMB/BSC-Dust model is its on-line coupling with the Non-hydrostatic Multiscale Model (NMMB). This provides a unique framework to simulate/predict weather and air quality in a wide range of scales from global to mesoscale applications (from 100 to $1 \mathrm{~km}$ ), and allows interactions among meteorology-dust-chemistry processes. The NMMB/BSC-Dust model solves the mass 
balance equation for dust taking into account the following processes: (1) dust generation and uplift by surface wind and turbulence (White, 1979; Marticorena and Bergametti, 1995; Marticorena et al., 1997), (2) horizontal and vertical advection (Janjic et al., 2005; Janjic and Black, 2007), (3) horizontal diffusion and vertical transport by turbulence and convection (Janjic et al., 2005; Janjic and Black, 2007) (4) dry deposition and gravitational settling (Zhang et al., 2001) and (5) wet removal which includes in-cloud and below-cloud scavenging from convective and stratiform clouds (Betts, 1986; Betts and Miller, 1986; Janjic, 1994; Ferrier et al., 2002). Transport of dust by advection and turbulent diffusion is analogous to those of moisture transport in the NMMB. The model includes 8 dust size bins (between $0.10-10 \mu \mathrm{m}$ in radius) with intervals taken from Tegen and Lacis (1996) and Peréz et al. (2006b).

Grid points acting as desert dust sources are specified using arid and semiarid categories of the global USGS 1-km vegetation data set and the STATSGO-FAO soil map global soil texture data set. According to the criteria used in Tegen et al. (2002), the model uses 4 soil populations (i.e., clay, silt, fine-medium sand and coarse sand). For the source function, the model uses the topographic preferential source approach after Ginoux et al. (2001) and the National Environmental Satellite, Data, and Information Service (NESDIS) vegetation fraction climatology (Ignatov and Gutman, 1998).

\subsubsection{Model experimental set-up}

We performed two regional NMMB/BSC-Dust experiments covering the Arabian Peninsula: a regional simulation which covers northern Africa, the Middle East and Europe (box window $0^{\circ}-70^{\circ} \mathrm{N}$ and $31^{\circ} \mathrm{W}-71^{\circ} \mathrm{E}$ ) with a grid spacing of $0.33^{\circ} \times 0.33^{\circ}$ (hereafter referred to as LR simulation); and a high-resolution simulation covering the Arabian Peninsula (box window $10^{\circ} \mathrm{N}-40^{\circ} \mathrm{N}$ and $35^{\circ} \mathrm{E}-65^{\circ} \mathrm{E}$ ) with a grid spacing of $0.03^{\circ} \times 0.03^{\circ}$ (hereafter referred to as HR simulation). The vertical resolution for both simulations is $40 \sigma$-hybrid layers with the top of the atmosphere at $50 \mathrm{hPa}$. The atmospheric model's fundamental time step was set to 40 and $25 \mathrm{~s}$, respectively for LR and HR experiments. The simulated dust distributions consist of daily ( 24 hours of forecast) runs for 10-20 March 2012. The NCEP/FNL final analyses (at $1^{\circ} \times 1^{\circ}$ ) at 0 UTC are used as initial meteorological conditions and boundary meteorological conditions at intervals of $6 \mathrm{~h}$. The model does not include dust data assimilation system. The initial state of the dust concentration is defined by $24-\mathrm{h}$ forecast of the previous-day model run. Only in the 'cold start' of the model, concentration is set to zero. In this contribution, simulations were carried with the operational RRTM radiation scheme (Mlawer et al., 1997) which allows feedback between dust and radiation.

\subsection{Observational datasets}

There are few available in-situ observations (such as AERONET stations), and very few international research campaigns that have been conducted in West Asia in comparison with other desert dust source regions such as the Sahara (Cuevas et al., 2013). To 
complement the model results, satellites and ground-based meteorological observations are included in the present analysis.

\subsubsection{Satellite aerosol products}

In the present analysis, the MSG/SEVIRI RGB dust product (http://www.eumetsat.int/) is used with a $3 \mathrm{~km}$ horizontal resolution, which is similar to the highest resolution $\left(0.03^{\circ} \times 0.03^{\circ}\right)$ of both proposed model configurations. The MSG/SEVIRI RGB dust product is qualitative and adimensional column-load product based on an RGB composite based upon infrared channels of SEVIRI. This RGB combination is designed to monitor the evolution of dust storms over deserts during both day and night, and it exploits the difference in emissivity of dust and desert surfaces, although it does, however, allow for the further ( 24 hour) tracking of dust clouds as they spread over the sea. In this RGB combination, dust appears pink or magenta.

The Moderate Resolution Imaging Spectroradiometer (MODIS; on-board the Aqua and Terra satellites) provides high radiometric sensitivity in 36 spectral bands ranging in wavelength from 0.4 to $14.4 \mu \mathrm{m}$ and provides global coverage every one to two days. The MODIS aerosol algorithm consists of two independent algorithms, one for deriving aerosols over land and the second for aerosols over ocean (Remer et al., 2002; Levy et al., 2010). However, the algorithm over land was developed only for low ground reflectance (i.e., over dark vegetation). For this reason, we also include the MODIS Deep Blue (DB) product which provides information over arid and semi-arid areas. The MODIS DB product employs radiances from blue channels for which the surface reflectance is low enough that the presence of dust brightens the total reflectance and enhances the spectral contrast (Hsu et al., 2004). Aqua/MODIS Level 2 (at $10 \mathrm{~km}$ x 10 $\mathrm{km}$ from the Collection 6) aerosol optical depth (at 550nm, AOD) data (cloud free) and the aerosol optical depth (at 550nm, AOD) DB products from Aqua/MODIS sensor are used in the following analysis.

\subsubsection{Ground-based observations}

Ground-based observations are very scarce close to dust source regions and available time series are relatively short and present many gaps. Surface weather observations from the Integrated Surface Hourly (ISH, https://www.ncdc.noaa.gov/isd) database archived at the National Climatic Data Center (NCDC) is composed of worldwide surface weather observations and includes data originating from various codes such as synoptic, airways, METAR (Meteorological Routine Weather Report), and SMARS (Supplementary Marine Reporting Station), as well as observations from automatic weather stations. In the present study in addition to wind speed, visibility is used as proxy information of the evolution of the dust event at surface level.

We use also column integrated aerosol optical properties routinely observed within AErosol RObotic NETwork (AERONET; Holben et al., 1998; Smirnov et al., 2000) sun 
photometers in the model comparison. These instruments rely on extinction measurements of the direct and scattered solar radiation at several nominal wavelengths (between 340 and $1020 \mathrm{~nm}$ ). In the present work, direct-sun quality-assured (level 2.0) data at Mezaira (MEZ) and Kaust Campus (KST) AERONET sites (see Figure 1) are included. In order to quantitatively compare the modelled optical data in the mid-visible spectrum, we selected AOD at $550 \mathrm{~nm}$ from AERONET observations, which is calculated from channels between 440 and $870 \mathrm{~nm}$ and following Ångström's law. AERONET measurements within \pm 90 min around the 3-hourly model outputs are averaged and used for the model comparison.

\subsection{Reanalysis meteorological data}

We use output from the ERA-Interim reanalysis (Dee et al., 2011; http://apps.ecmwf.int/datasets/data/interim_full_daily/) to compare meteorological fields and spatial patterns. ERA-Interim is the latest global atmospheric reanalysis produced by the European Centre for Medium-Range Weather Forecast (ECMWF) as a transition between ERA-40 and a future reanalysis project. It provides information on a large variety of surface parameters (on 3-hourly basis), describing weather as well as ocean-wave and land-surface conditions and 6 hourly upper-air parameters (37 pressure levels up to $1 \mathrm{hPa}$ ), on a $0.25^{\circ}$ x $0.25^{\circ}$ grid. ERA-Interim uses an improved atmospheric model and a more sophisticated data assimilation method (4-D-Var) for atmospheric analysis compared with ERA-40. In the present analysis, $10 \mathrm{~m}$ wind fields and the geopotential height at $700 \mathrm{hPa}$ are included.

\section{Results and discussion}

\subsection{Study case: Dust storm outbreak on March 2012}

Two intense dust storms occurred in West Asia on 17 - 20 March 2012 that spanned thousands of kilometres from the Red Sea to Afghanistan, and affected the whole Arabian Peninsula (see Figure 2). 
MSG RGB Dust
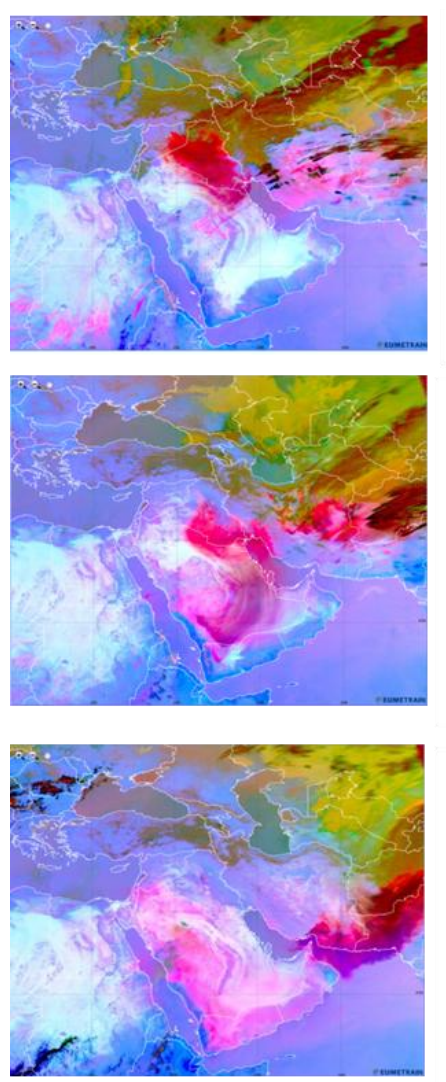

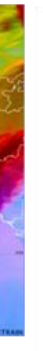

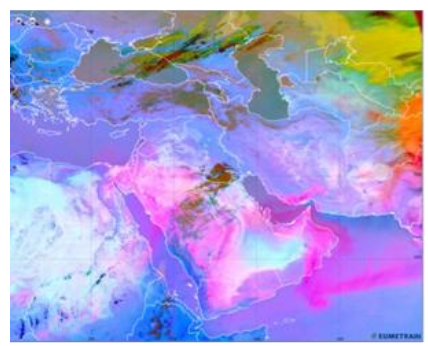

Visibility (m)
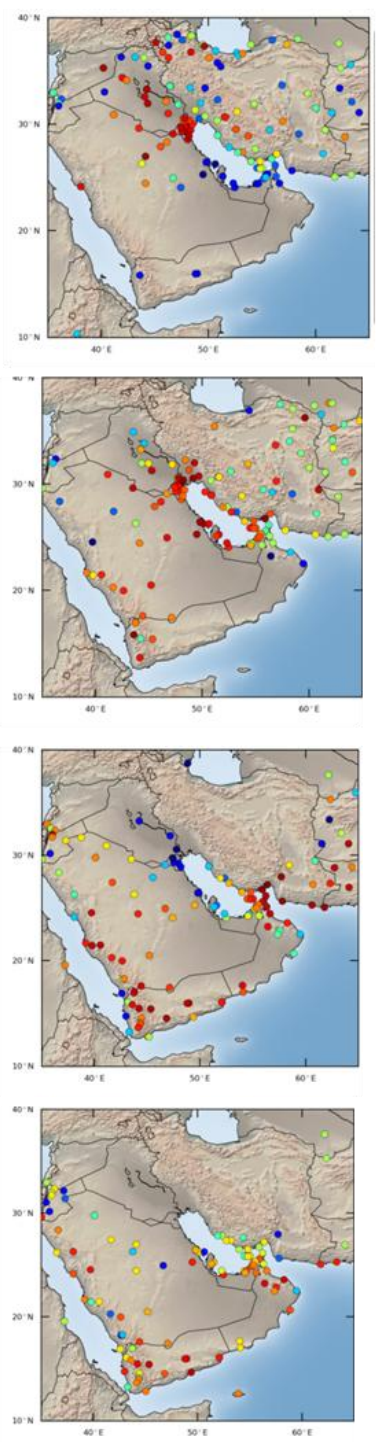

\section{MODIS/Aqua}
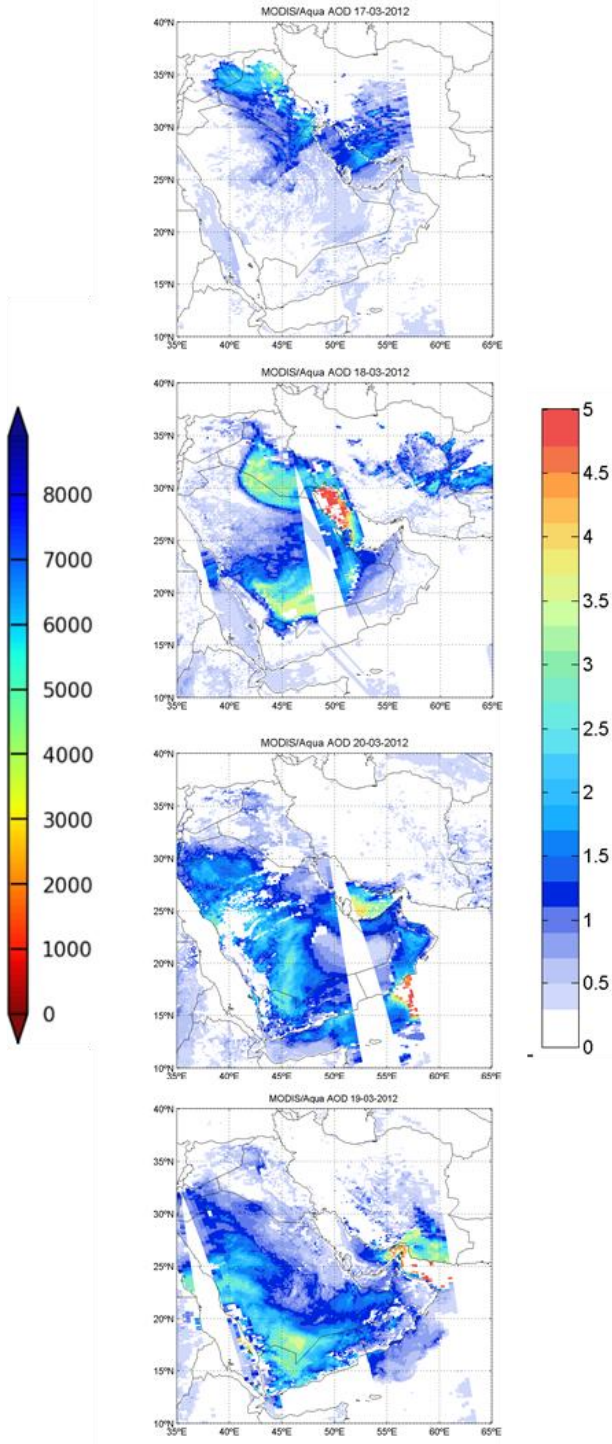

Figure 2. Observed dust concentrations from 17 - 20 March) at 12UTC (in rows). First column: MSG Dust product; second column: visibility (in meter) from surface weather stations; third column: aerosol optical depth (AOD) at 550nm from Aqua/MODIS. These images correspond to the combined Level 2 (at $10 \mathrm{~km} \mathrm{x}$ $10 \mathrm{~km}$ ) aerosol product from Aqua/MODIS between 9 and 12 UTC.

On March 17, 2012, a dust storm developed as a result of Shamal (nortwesterly) winds (i.e. behind an advancing cold front, see Figure 3) crossing Iraq towards the Arabian Gulf as shown in Figure 2. This storm is in the range of the most powerful dust events considered in the literature as confirmed Prakash et al. (2014). The origin of this event is localized over the Tigris and Euphrates rivers basin in Iraq as confirmed the analysis from Al-Yahyai and Charabi (2014). The upper air profile of the Iraq Desert on March 17 showed that the northwesterly winds were extended up to $700 \mathrm{hPa}$ level due to a high pressure system over the Arabian Peninsula (Figure 3). The intensified northwesterly wind caused dust to rise from the Iraq Desert area and move in a southeasterly direction affecting Iraq, Kuwait, Bahrain, Qatar, Kingdom of Saudi Arabia, United Arab Emirates 
(UAE), and to reach Oman and Yemen the next days achieving AOD up to 3.5 and reducing drastically the visibility less than $300 \mathrm{~m}$ in sites in the Persian Gulf (see Figure 2). Between 18 - 19 March, satellite aerosol images (Figure 2) show how the dust plume posteriorly extended towards the inner Rub'al Khali desert and reached the Asir mountains of western Saudi Arabia, and Yemen where it was blocked by the topography and spread through the valley that channelize the dust flow towards the Arabian Sea.

ERA-Interim
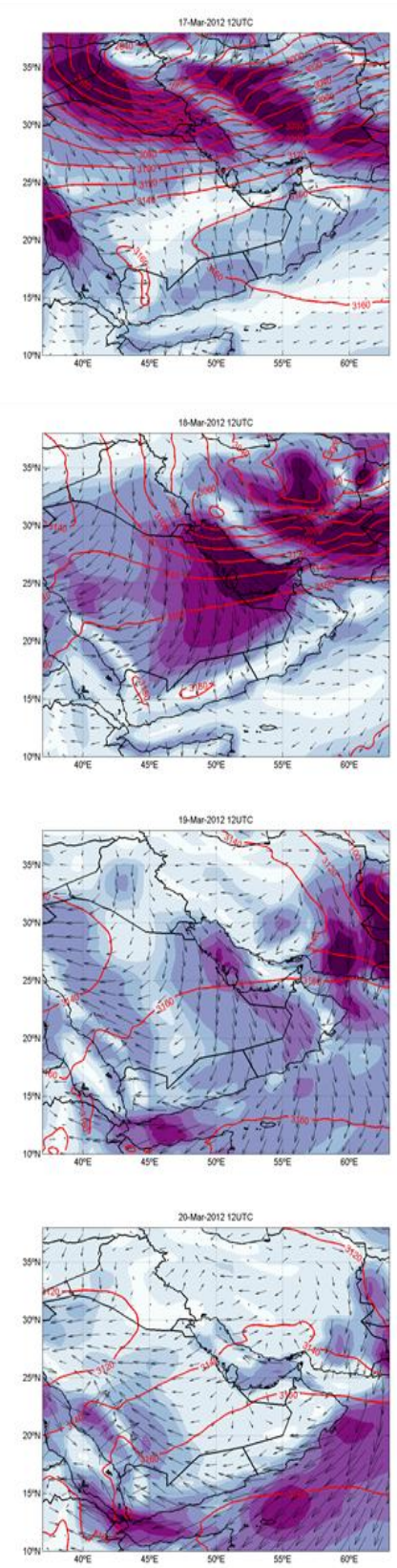

LR
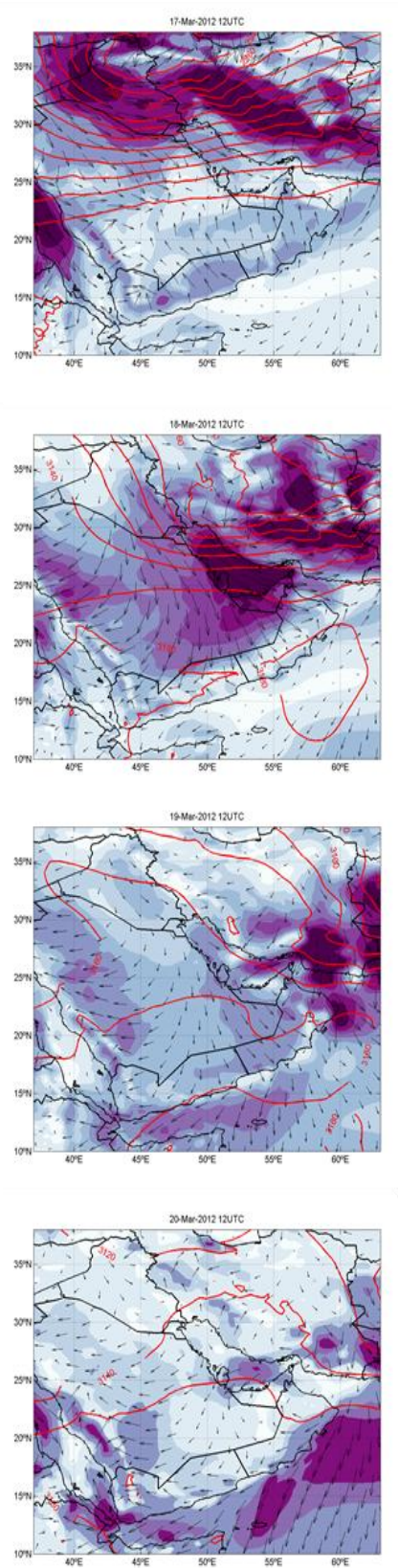

HR
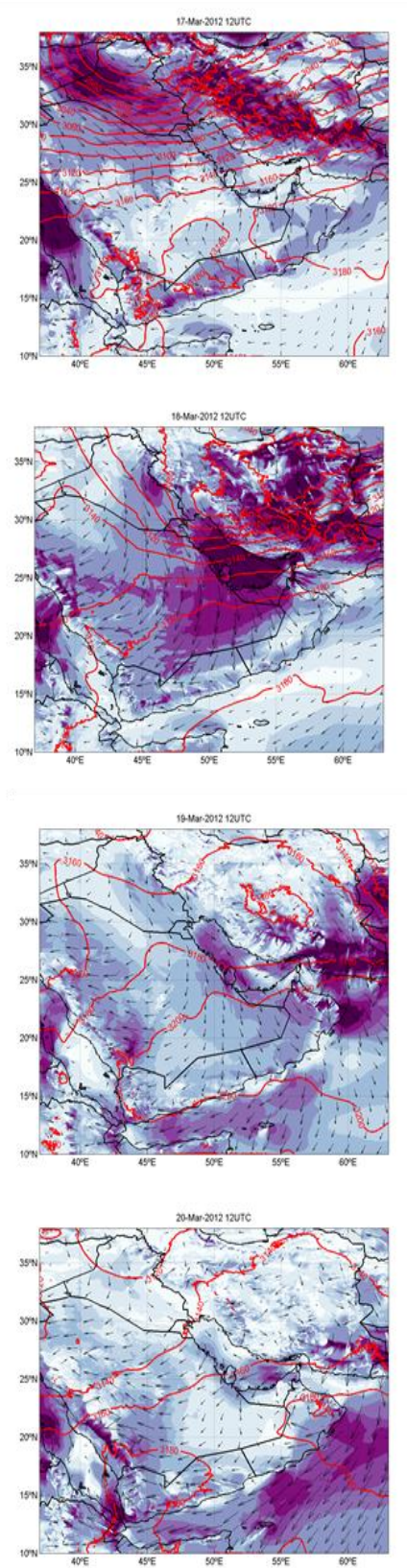

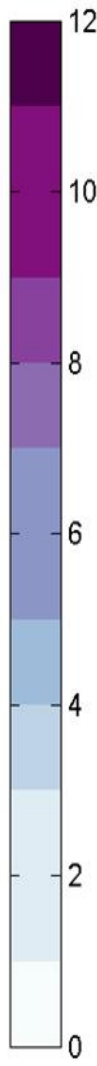

Figure 3. Modelled geopotential height (red colour solid line) at $700 \mathrm{hPa}$ and surface winds at $10 \mathrm{~m}$ (the colour indicates the wind speed and the black arrows the wind vector fields) from 17 to 20 March (in rows) at 12UTC for the ERA-Interim reanalysis at $0.25^{\circ} \times 0.25^{\circ}$ (right panels) as well as for the NMMB/BSC-Dust model at $0.33^{\circ} \times 0.33^{\circ}$ resolution (LR, central panels) and at $0.03^{\circ} \times 0.03^{\circ}$ resolution (HR, left panels). 
While the dust storm was still crossing the Arabian Peninsula, on March 18, 2012, another dust storm formed over the Iran Desert and moved southerly towards Oman (Figure 2). Al-Yahyai and Charabi (2014) localized the origin of this second storm over Iran, in the Sistan and Baloushistan basin which covers the borders where Afghanistan, Pakistan and Iran meet. A trough (which crossed Iraq before) passed the Iran Desert, the high pressure intensified (Figure 3), and the surface northerly wind strengthened and blew the dust towards the south to the Oman sea coasts and the Arabian Sea (Figure 2). On 19 March, the second dust front associated to the dust outbreak with origin in Iran was blocked by the Al-Hadjar Mountains in northeaster Oman forcing dust to move towards the Arabian Sea giving AOD up to 4 over Oman and reducing the visibility to less than 500m in northern Oman and southern Iran (see Figure 2). The following days, the intense dust storm spanned thousands of kilometers over the Arabian Sea reaching the Yemeni and Somalian coasts.

\subsection{Model comparison}

In the present section, modelled dust fields are compared against observational data introduced in Sect. 2.2. Simulated topography by HR represents mountain ranges, valleys, coastlines and small islands better than LR with height differences of up to 1 $\mathrm{km}$, although these height differences are even higher in steep and narrow mountain ranges in Oman, Iran, Yemen and Saudi Arabia (Figure 1).

Simulated meteorological (Figure 3) and airborne dust distributions (Figure 4) are able to reproduce the main features observed at ground level (i.e. visibility and winds) and column-load dust aerosol satellite retrievals (Figure 2). Both simulations (LR and HR) reproduce the northwesterly winds which are extended up to $700 \mathrm{hPa}$ level due to a high pressure system over the Arabian Peninsula as it is also observed in the ERA-Interim fields (Figure 3). The intensified northwesterly wind caused an increase of the surface winds from the Iraq Desert area and move in a southeasterly direction achieving up to $12 \mathrm{~m} / \mathrm{s}$ over the Persian Gulf on $19^{\text {th }}$ March (Figure 3). Also, they follow the reduction of the visibility observed by the ground-based observations and the increasing of observed column-load aerosol fields by the satellites (see Figure 2). However, inconsistency between concentration modelled fields and observations can be detected in some areas. High satellite AOD (up to 5) and low surface visibility are observed over the Persian Gulf on $18^{\text {th }}$ March (see Figure 2). These high aerosol concentrations do not have correspondence with modelled dust fields (see dust optical depth $<1$ in Figure 4). Despite visibility observations are dust-dominated phenomena, aerosol concentrations in this region is also influenced by local high humidity contents in near-coastal areas and/or aerosols from anthropogenic activities in the region (Basart et al., 2009) inducing the observed model underestimation. 

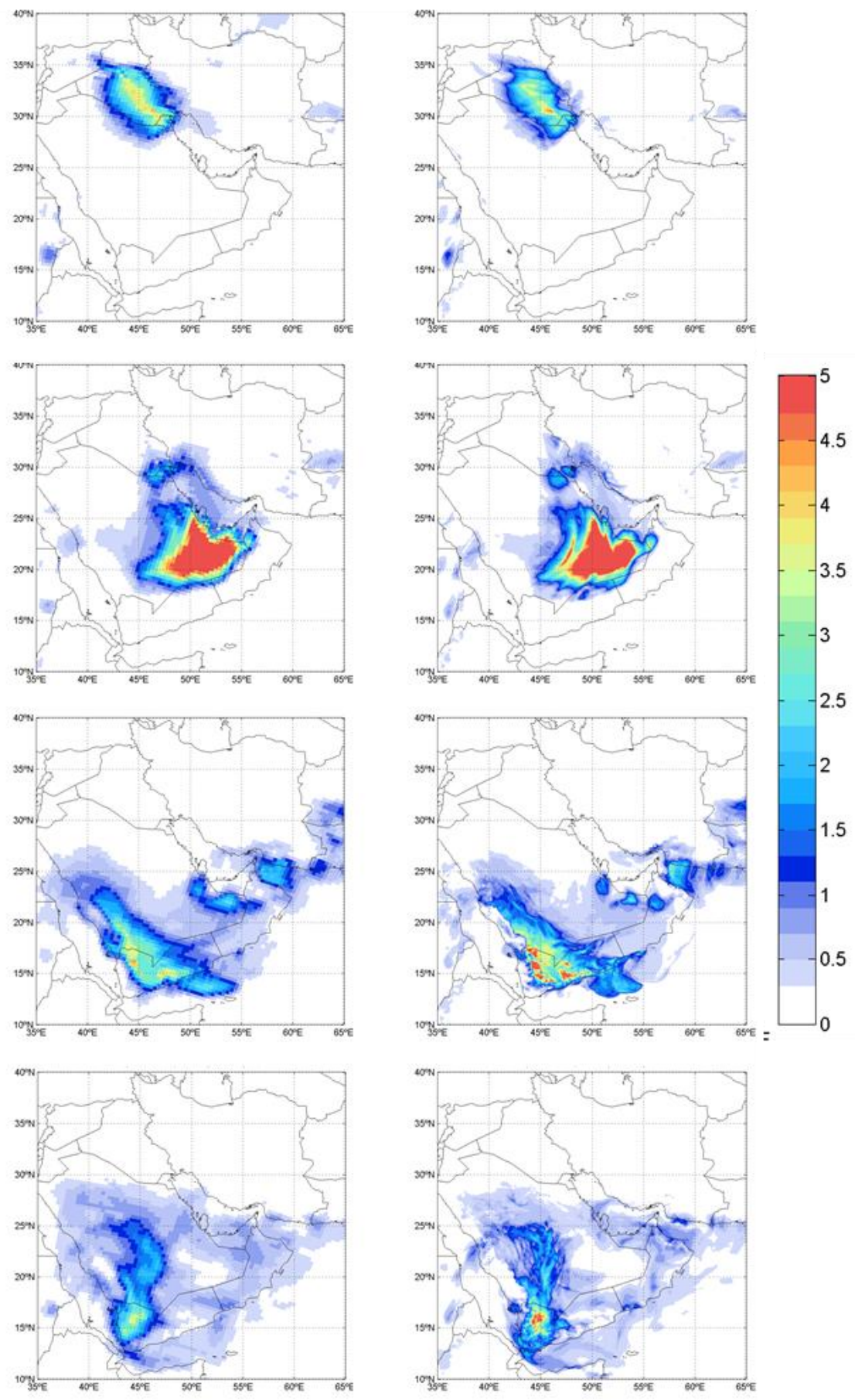

Figure 4. Modelled dust optical depth at 550nm (right panels) at 12UTC from 17 to 20 March (in rows) at for the NMMB/BSC-Dust model at $0.33^{\circ} \times 0.33^{\circ}$ resolution (LR) and at $0.03^{\circ} \times 0.03^{\circ}$ resolution (HR).

On 17 March, both model simulations show how dust rises from the Iraq Desert and moves in a southeasterly direction affecting the entire Arabian Peninsula and reaching Oman and Yemen on the following days (see Figure 4). However, the model underestimates the dust concentrations during 18 March over Iraq and Kuwait and overestimates the dust concentrations (AOD > 5) during its transport in the middle of 
the Arabian Peninsula the following days as shown in the satellite comparison in Figure 2. This is also confirmed by the Mezaira AERONET comparison (see 18 March in Figure 5). On 17 March, both simulations present wind overestimations over the main dust sources in Iraq and wind underestimations in Kuwait in comparison with surface weather stations at 12 UTC (MB up to $-8 \mathrm{~m} / \mathrm{s}$; Figure 6), when the emission of the first event is produced. During the following hours, dust transports south (see Figure 4) and during its southeasterly trajectory is affected by a high wind underestimation in both simulations (up to $8 \mathrm{~m} / \mathrm{s}$; see Figure 6 ). As a consequence of that, both simulations show low AOD values (Figure 4) over Iraq and Kuwait on 18 March in comparison with Aqua/MODIS AOD, and furthermore both present a delay in the arrival of the dust front to the South Arabian Peninsula of about 8 hours (see Figure 4 on March 18 at 12 UTC). This delay is linked to the NCEP/FNL meteorological fields that are used initial and boundary meteorological conditions in the simulations. This run late in the NMMB/BSC-Dust model is also observed in the comparison with the surface winds against ERA-Interim (Figure 3).

When the dust plume arrives to Qatar and the UAE on 18 March, a large area between the coast and the Rub'Al-Khali desert quickly actives, reaching simulated AOD larger than 5 (Figure 4), which clearly overestimate the satellite aerosol retrievals (Figure 2). The Mezaira AERONET station (in the southern UAE; see 18 March in Figure 5) also reported this AOD overestimation, which is mainly driven by the high dust emission from the UAE coast. At that time, ERA-Interim (Figure 3) reproduces strong northerly winds $(>12 \mathrm{~m} / \mathrm{s})$ across the Persian Gulf hit the UAE coast, which were overestimated as reported some surface weather stations (above $4 \mathrm{~m} / \mathrm{s}$, see Figure 6), although with higher values in the LR simulation, which is also associated with a high AOD peak than HR simulation in the Mezaira AERONET site (Figure 5).

(a)

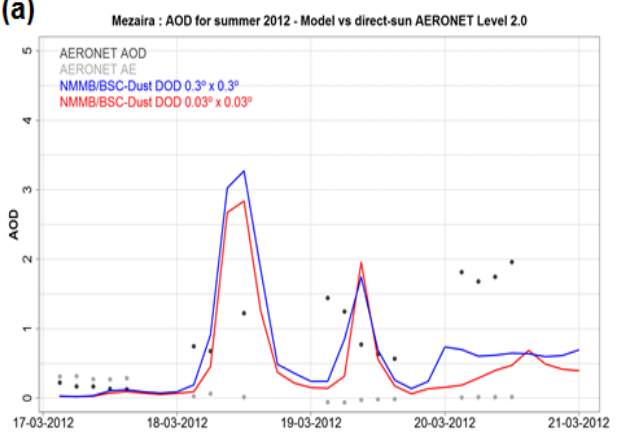

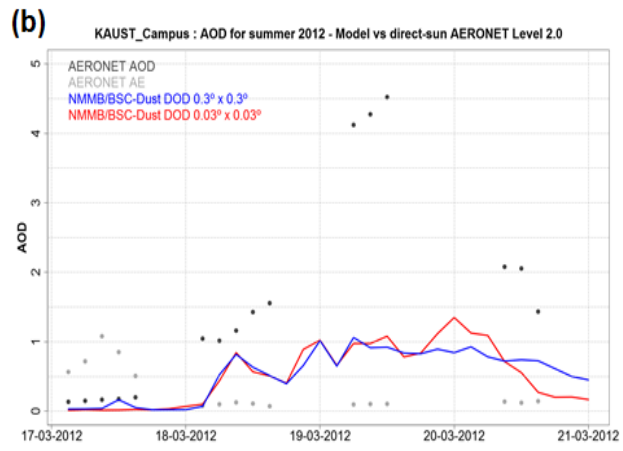

Figure 5. Modelled and observed aerosol optical depth $550 \mathrm{~nm}$ (at 3-hourly temporal resolution) for (a) Mezaira (MEZ) and (b) Kaust Campus (KST) AERONET sites. The Ångström's exponent (AE; between 440 and $870 \mathrm{~nm}$ ) is added as proxy information of the presence of coarse mineral dust in the observation point $(\mathrm{AE}<0.75)$. The localization of both sites is shown Figure 1.

On 19 March, we can observe a sharp increase in the modelled AOD that is not observed by the Mezaira AERONET sunphotometer (see the second AOD peak in 
Figure 5). This high dust emission from Rub'Al Khali is associated with a wind increase winds, which is reported by coastal station in the UAE between 6 and 9 UTC 19 March (not shown here), favouring dust emission in this area. These local emissions are associated with coarse fractions that rapidly deposited back on the ground. On 20 March, when the dust front with origin in Iran arrives to the Omani coast (Figure 2), LR presents dust arrival to the Meizara AERONET station 12 hours earlier than HR (Figures 5). This is associated with a lower topography and fewer obstacles for wind flows, which were mostly overestimated along its trajectory towards the UAE. On the contrary, the blowing dust by winds in the HR simulation had to overcome and circle higher topographic obstacles, delaying its advance as it is observed in Aqua/MODIS and MSG/SEVIRI RGB dust products on 19 and 20 March (Figure 2).

On the other hand, the AERONET comparison in Kaust Campus AERONET site shows how the maximum dust concentration is found on 19 March. Both model simulations (LR and HR) underestimate the observed AOD (Figure 5). The Kaust Campus AERONET sunphotometer is located in a rural region just at the sea shore in Thuwal (Saudi Arabia, see the KST label in Figure 1). Both model simulations (LR and HR) reproduce the observed dust presence; however they underestimate the observed values that achieve values up to 4.5 as shown in the Kaust Campus AERONET site (Figure 5). Both model simulations (LR and HR) show that dust emission originated in a litoral area of the Red Sea (Figure 7) where the surface winds achieve values $>12 \mathrm{~m} / \mathrm{s}$ on 18 March at 12UTC (Figure 3). Additionally, as a result of the dust blocking over Asir Mountains, dust is forced to move to this site (see Figure 4) in better agreement with HR (see Figure 5).

On 18 March, both simulations show high aerosol concentrations over southearstern Iran, southwestern Pakistan and along the border of Iran, Pakistan and Afghanistan (see Figure 4), where the second dust event origins. Both model simulations strongly underestimate the intensity of this dust outbreak in the comparison with Aqua/MODIS AOD (Figures 2), which can be associated with several factors such as a poor representation of the alluvial sources which are highly presented over the region. During this event, the dust outbreak moved south affecting the Oman sea coasts and the Arabian Sea.

Prakash et al. (2014) simulated the period between 17 and 20 March by means of the WRF-Chem model (at $10 \mathrm{~km}$ horizontal resolution and 40 vertical levels) to quantify the effects of severe dust events on radiation fluxes and regional climate characteristics in the Arabian Peninsula and the Red Sea. In this study, even though the magnitude of the simulated AOD at the Kaust Campus site was lower compared to that of AERONET during 19 March, the simulations were able to reproduce the peak AOD and the temporal dependence quite well as is the case with both LR and HR simulations used in the present study. 


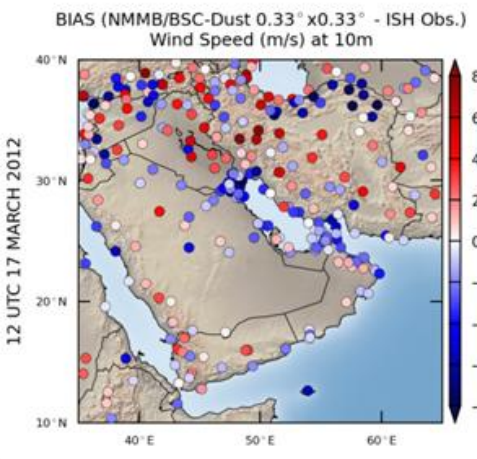

BIAS (NMMB/BSC-Dust $0.03^{\circ} \times 0.03^{\circ}=1$ ISH Obs.)
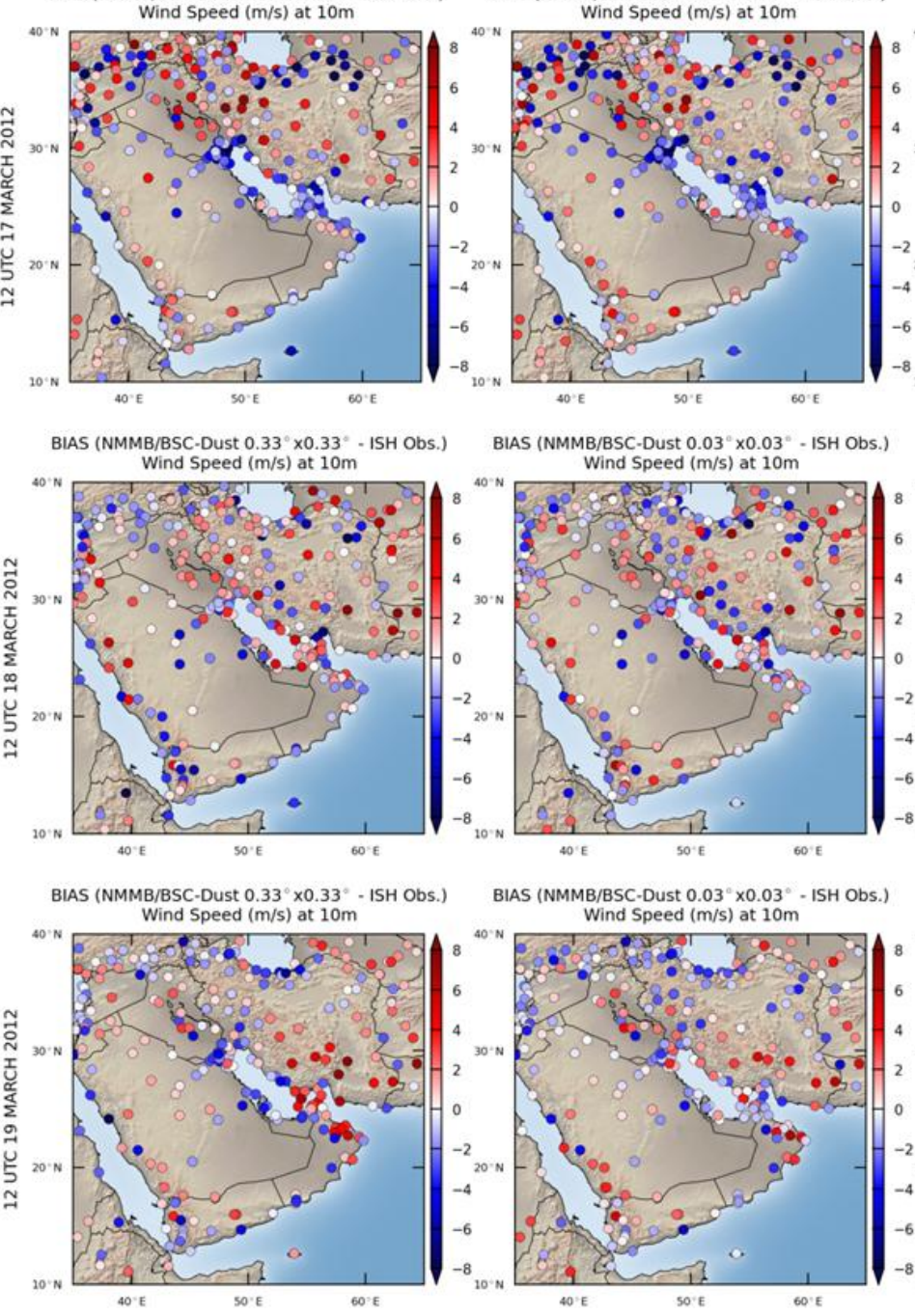

BIAS (NMMB/BSC-Dust $0.33^{\circ} \times 0.33^{\circ}-1$ ISH Obs.) BIAS (NMMB/BSC-Dust $0.03^{\circ} \times 0.03^{\circ}-$ ISH Obs.)
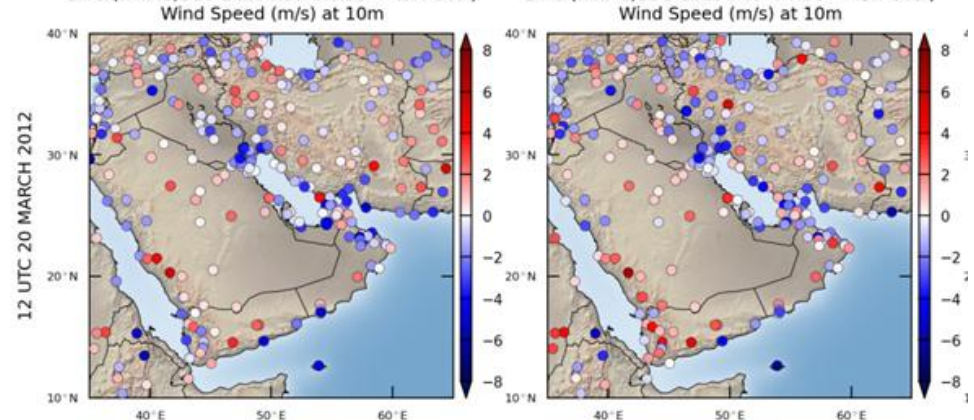

Figure 6. Mean Bias between modelled and observed wind speed at $10 \mathrm{~m}$ at 12 UTC for the NMMB/BSCDust model at $0.33^{\circ} \times 0.33^{\circ}$ resolution (LR, left) and at $0.03^{\circ} \times 0.03^{\circ}$ resolution (HR, right).

Discrepancies between different model configurations are not easily attributed to specific model aspects. The NMMB/BSC-Dust model's emission scheme is a function dependent on the cubic wind speed and several soil features above a given threshold (White, 1979). Misrepresentations of soil features (not studied here) and of wind speed can lead to emission bias. Furthermore, including a topographic preferential source mask in the model's emission scheme can inhibit the dust emissions in the western coast 
of the Arabian Peninsula. In order to improve the model's ability to estimate dust
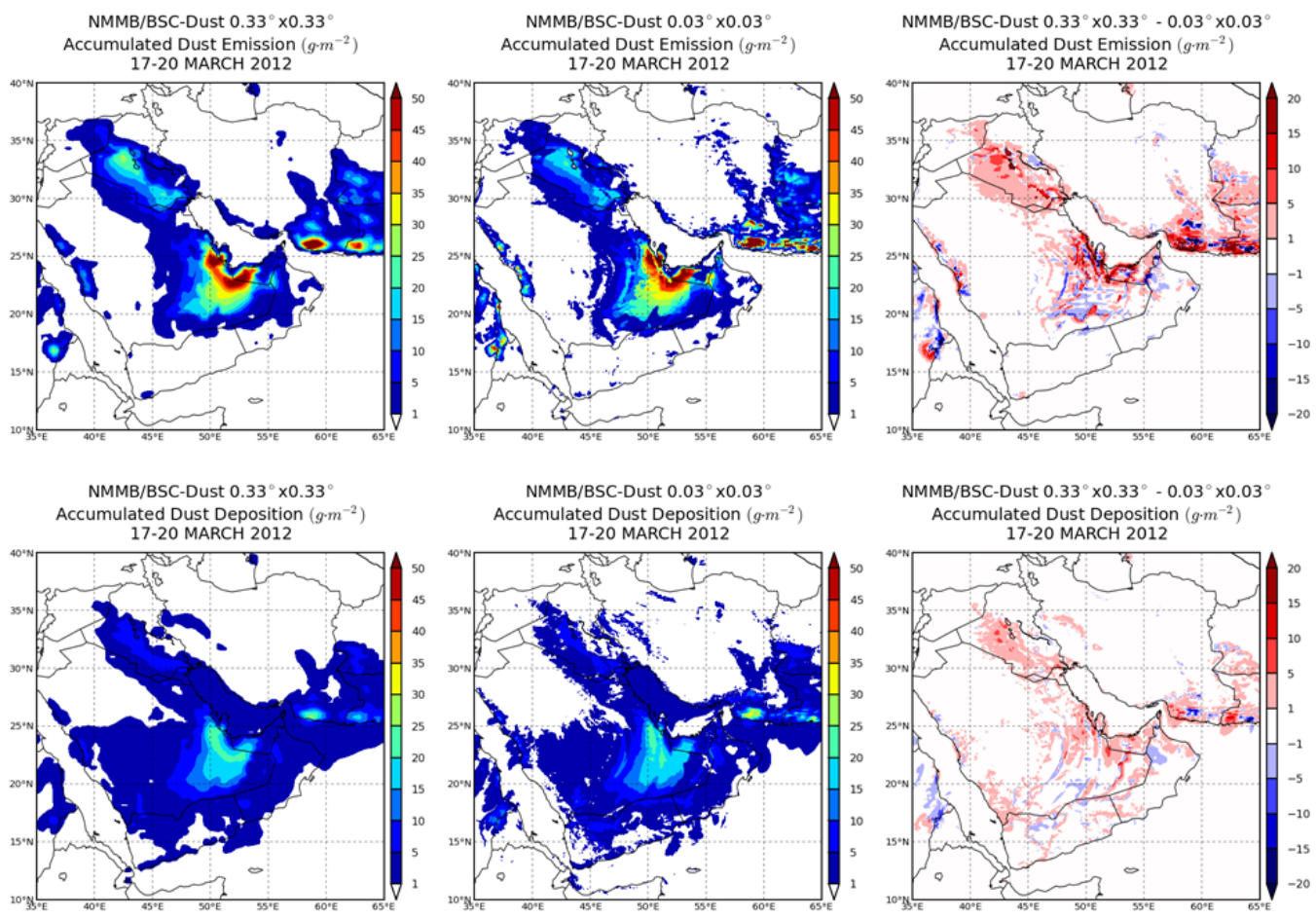

Figure 7. Modelled accumulated emission (top row) and deposition (bottom row) fields from 17 to 20 March at for the NMMB/BSC-Dust model at $0.33^{\circ} \times 0.33^{\circ}$ resolution (LR) and at $0.03^{\circ} \times 0.03^{\circ}$ resolution (HR) as well as their respective differences. Highest differences in the emissions close to mountains ranges are artefacts associated to the interpolation applied to do the difference maps. 


\subsection{Topographic effects on the dust transport}

In both dust events observed between 17 and $20 \mathrm{March}$, the topography plays key roles in wind patterns that affect the blocking and changes the trajectories of the blowing dust. West Asia is particularly sensitive to these topographic effects and the model spatial resolution can be crucial in allowing for a better representation of the dust propagation. In the present section, we focus on specific cases for both presented dust events where the topographic effect on wind patterns and dust propagation were relevant. The presented cases are based on 19 March (see Figure 8): (1) dust blocking on Hadramawt and Asir Mountains and dust channelling between these mountains that extended over the Arabian Sea; and (2) dust channelling in Iran and the dust blocking in the Al-Hadjar Omani mountains.

Hadramawt Mountain ranges in Yemen are lower represented in the LR simulation than the HR simulation (see Figure 1). In both simulations they are high enough to block the dust flow from the Saudi Arabia on 18-20 March, causing a large accumulation of dust over the inner Yemen and on the windward side of its mountains (Figure 4) as it is also observed in the satellite aerosol products (Figure 2). However, the LR simulation omits the narrow valleys between the Hadramawt Mountains and river valleys through of where the wind channel the dust and which are well-reproduced in the HR simulation (see Figure 8e-1). Through some of these valleys, wind channelling transports dust towards the coastal areas. Wind fields are highly in the vicinity of theses mountain ranges with locally wind speed differences of up to $8 \mathrm{~m} / \mathrm{s}$ and large changes in the wind directions (Figure 6). Over the Arabian Sea, in the HR simulation shows how intensified dusty winds (up to $18 \mathrm{~m} / \mathrm{s}$, Figure 3 ) through the valleys were able to describe these dust channelling structures in a qualitatively comparison with satellite images (Figure 8a and $8 b)$.

As expected, the definition of the topography modifies the temperature vertical structure profiles and consequently the dust peak. The higher mountain elevation of the HR simulation is also has associated with stronger subsidence in the leeward of the Asir mountains (see the cross sections along $15^{\circ} \mathrm{N}$ and $45^{\circ} \mathrm{E}$ in Figure 8). The rapid vertical dust extension over the high elevations observed in both model simulations with the peak of dust vertical mixing at about 15 UTC (see the cross section along $15^{\circ} \mathrm{N}$ in Figure $8 \mathrm{f}$ and Figure $8 \mathrm{~g}$ ) are associated with the rapid growth of the planetary boundary layer (PBL) over the high elevations in the western Arabian Peninsula as indicated by Prakash et al. (2014). The PBL in the Arabian Peninsula can be influenced by different mechanisms associated with coastal breezes, terrain and surface properties. During the day, the surfaces of the mountains heat the air higher up in the atmosphere. 

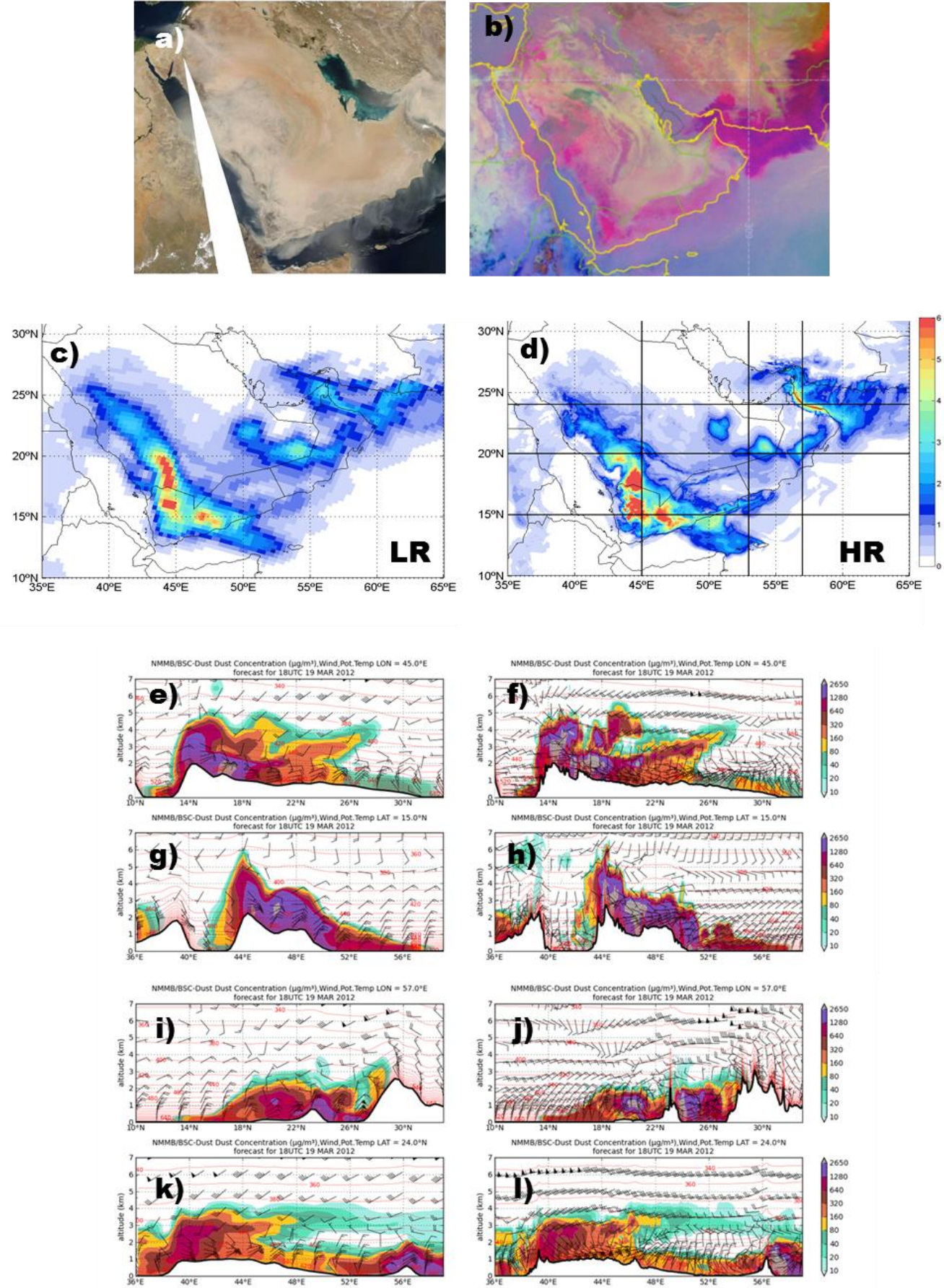

Figure 8. a) Aqua/MODIS at 09:50 UTC and 10:05 UTC on 19 March. b) MSG/RGB image for 19 March at 15:15 UTC. Modelled dust load (in $\mathrm{g} / \mathrm{m}^{2}$ ) from 19 March at 15UTC at for the NMMB/BSC-Dust model c) at $0.33^{\circ} \times 0.33^{\circ}$ resolution (LR) and d) at $0.03^{\circ} \times 0.03^{\circ}$ resolution (HR). e-l) Modelled vertical dust concentration cross sections (in $\left.\mu \mathrm{g} / \mathrm{m}^{3}\right)$ at fixed latitudes $\left(15^{\circ} \mathrm{N}\right.$ and $\left.24^{\circ} \mathrm{N}\right)$ and longitudes $\left(45^{\circ} \mathrm{E}\right.$ and $\left.57^{\circ} \mathrm{E}\right)$ and on 19 March at $12 \mathrm{UTC}$ for $0.3^{\circ} \mathrm{x} 0.3^{\circ}$ and $0.03^{\circ} \mathrm{x} 0.03^{\circ}$ horizontal resolution.

On 19 March at 12 UCT, both model simulations (LR and HR) predicted the arrival of a dust front into Oman, where it is blocked at low altitude by the Al-Hajar mountain range (Figure 4). Both simulations, highly underestimating the magnitude of real intrusion over the station as it is indicated in Section 4.2. The LR simulation presents a dust arrival to Mezaira station 12 hours earlier than the HR simulation (Figure 5), which 
is associated with a lower topography and fewer obstacles for wind flows, which are blowing dust by winds in the HR simulation has to overcome and circle higher topographic obstacles, delaying its advance. Figure 8 shows how the higher topography simulated by the HR simulation left more dust on the Omani coast, especially in its central section where the highest mountains (Al-Hajar with up to $3000 \mathrm{~m}$ ) are. The dust front is initially blocked by the mountains on 19 March and, consequently, low AOD values are shown on its leeward side on 20 March as it is observed in the satellite images (Figure 2). Topographic effects on wind patterns (e.g., channelling or blocking) are better represented in the HR simulation with high wind speed bias reductions and more realistic wind directions than in the LR simulation (Figure 3 and Figure 6). On 19 March at 15 UTC in Oman, both model simulations predict the dust arrival to the mountain system achieving altitudes above $3 \mathrm{~km}$ a.s.l (see the cross sections along $24^{\circ} \mathrm{N}$ in Figure 8). In this event, the HR simulation is able to better reproduce the blocked dust mass upwind of the mountains observed in the MSG/SEVIRI RGB dust image as it is shown in the cross sections along $24^{\circ} \mathrm{N}$ at $15 \mathrm{UTC}$ in Figure $8 \mathrm{k}$. In the LR simulation, high concentrations are shown on its leeward side on 19 March at 15 UTC (AOD up to 5 in Figure 8c and concentrations above to $2650 \mu \mathrm{g} / \mathrm{m}^{3}$ in Figure 8k) in comparison to concentrations predicted by the LR simulation (AOD up to 2 in Figure $8 \mathrm{~b}$ and concentrations up to $2500 \mu \mathrm{g} / \mathrm{m}^{3}$ in Figure $8 \mathrm{j}$ ).

\section{Conclusions}

In the present work, two model simulations based on the NMMB/BSC-Dust model are used to simulate two intense dust storms that occurred in West Asia on 17-20 March 2012 that spanned thousands of kilometres from the Red Sea to Afghanistan, and affected the whole Arabian Peninsula. In addition to providing an accurate overview of these dust storms, this study analyses the impact of model resolution on the description of the terrain relief and its consequence in the dust propagation. A high-resolution simulation (at $0.03^{\circ} \times 0.03^{\circ}$ horizontal resolution; hereafter referred as HR) of the NMMB/BSC-Dust model is analysed jointly to a configuration simulation at coarser resolution (at $0.33^{\circ} \times 0.33^{\circ}$ horizontal resolution; hereafter referred as LR).

Synoptic analysis done for West Asia using the ERA-Interim and the NMMB/BSC-Dust models shows that on 17 March 2012, a dust storm is developed as a result of a winter northwesterly Shamal wind crossing Iraq towards the Arabian Gulf. Satellite aerosol products (i.e. Aqua/MODIS AOD and MSG/SEVIRI RGB) and ground-based observations (surface weather and AERONET stations) show that the event achieves AOD values up to 5 and reduces the visibility to less than $300 \mathrm{~m}$. The NMMB/BSCDust model simulations indicate that the main dust sources during this event are in the river valleys of the lower Tigris and Euphrates in Iraq, Kuwait, Iran, the UAE and the Arabian desert that includes the Rub' Al Khali, An Nafud and Ad Dahna regions. Dust sources are also detected along the Red Sea coast in the western Arabian Peninsula. 
This dust storm affected all Arabian Gulf countries. This event was followed by another dust storm formed over the Iran Desert on 18 March 2012, and moved south reaching Oman and the Arabian Sea during the following days.

The dust evaluation results demonstrate that despite differences in the magnitude of the simulated dust concentrations, both model configurations are able to reproduce these two dust outbreaks. Differences on the dust spread between both simulations rise on regional dust transport areas in south-western Saudi Arabia, Yemen and Oman where a complex topography with several peaks higher than $3000 \mathrm{~m}$ is present. Both model simulations present a delay in the arrival of the dust front to South Arabian Peninsula of about 8 hours. This is linked the meteorological data required to initialize the atmospheric part of the model and to update its boundary conditions can introduce uncertainties too. On 19 March, the model overestimates dust emissions in Rub'Al Khali Desert (Saudi Arabia) and underestimates the event with origin in southern Iran. The overestimation in Rub'Al Khali Desert is associated with coarse fractions that are rapidly removed from the atmosphere. Otherwise, underestimations in Iran are linked to a combination of a poor representation of the desert dust sources in the model.

It is not straightforward to attribute the discrepancies to specific aspects of the model since the emission scheme depends on multiple surface, soil, and meteorological features and includes threshold processes and non-linear relationships. In this sense, the topographic preferential source map used in the model does not well-describe the sources located in the western coast of the Arabian Peninsula leading an underestimation of the dust emission. These results highlights the need to do a revision of the land-surface datasets used by the model to generate the source mask over Middle East.

The analysis of two model simulations (LR and HR) on 19 March shows that the complex orography in south-western Saudi Arabia, Yemen and Oman modifies the simulated dust concentration fields over mountain regions. On 19 March, the first dust front is blocked by the mountains in south-western Saudi Arabia, Yemen and Oman and spread through the valley that channelize the dust flow towards the Arabian Sea. On the other hand, the second dust front associated with the dust outbreak with origin in Iran is blocked by the Al-Hadjar Mountains in northeaster Oman forcing dust to move towards the Arabian Sea. Differences between both model configurations are mainly associated with the description of the topography and its effects on meteorology such as changes in wind speed and direction (e.g., channeling or blocking winds) that modify transport of dust.

The present analysis demonstrates the benefits of the use high-spatial resolution simulations to refine the description of mountain system and consequently to improve the prediction of regional dust transport fields over West Asia. 


\section{Acknowledgements}

We would like to acknowledge the AERONET and PHOTONS networks, which kindly provided their data, and the research groups that contribute to the networks. We also acknowledge the MSG and MODIS mission scientists and associated EUMETSAT and NASA personnel for the production of the data used in this research effort. S. Basart acknowledges the CICYT project (CGL2013-46736) and L. Vendrell acknowledges La Caixa foundation. The authors would like to special thank Dr. Oriol Jorba and Dr. Enza Di Tomaso for comments on the manuscript and K. Serradell and F. Benincasa for the technical support. All simulations were performed on the MareNostrum supercomputer hosted by BSC.

\section{References}

Al-Yahyai, S., and Charabi, Y., 2014. Trajectory Calculation as Forecasting Support Tool for Dust Storms, Advances in Meteorology, 2014, 698359, http://dx.doi.org/10.1155/2014/698359.

Amiridis V., U. Wandinger, E. Marinou, E. Giannakaki, A. Tsekeri, S. Basart, S. Kazadzis, A. Gkikas, M. Taylor, J.M. Baldasano and A. Ansmann., 2013. Optimizing Saharan dust CALIPSO retrievals. Atmos. Chem. Phys. Special Issue: Desert dust and its impact on air quality and climate, 13, 12089-12106, 14749-14795 www.atmos-chem-phys.net/13/12089/2013/ doi:10.5194/acp-13-12089-2013.

Badia, A., and Jorba, O., 2014. Gas-phase evaluation of the online NMMB/BSC-CTM model over Europe for 2010 in the framework of the AQMEII-Phase2 project. Atmospheric Environment. http://dx.doi.org/10.1016/j.atmosenv.2014.05.055

Basart, S., Pérez, C., Cuevas, E., Baldasano, J. M., and Gobbi, G. P., 2009. Aerosol characterization in Northern Africa, Northeastern Atlantic, Mediterranean Basin and Middle East from direct-sun AERONET observations, Atmos. Chem. Phys., 9, 8265-8282.

Basart, S., Pérez, C., Nickovic, S., Cuevas, E. and Baldasano, J.M., 2012. "Development and evaluation of the BSC-DREAM8b dust regional model over Northern Africa, the Mediterranean and the Middle East", Tellus B, 64, 18539, doi: http://dx.doi.org/10.3402/tellusb.v64i0.18539.

Benedetti, A., Morcrette, J.-J., Boucher, O., Dethof, A., Engelen, R.J., Fisher, M., Flentjes, H., Huneeus, N., Jones,L., Kaiser, J.W., Kinne, S., Mangold, A., Razinger, M., Simmons, A.J., Suttie, M., the GEMS-AER team., 2009. Aerosol analysis and forecast in the ECMWF Integrated Forecast System. Part II: Data assimilation, J. Geophys. Res., 114, D13205, doi:10.1029/2008JD011115.

Betts, A. K. and Miller, M. J., 1986. A new convective adjustment scheme, Part II: Single column tests using GATE wave, BOMEX, ATEX and arctic air-mass data sets, Q. J. Roy. Meteorol. Soc., 112, 693-709, doi:10.1002/qj.49711247308.

Betts, A. K., 1986. A new convective adjustment scheme. Part 1: Observational and theoretical basis, Q. J. Roy. Meteorol. Soc., 112, 677-691, doi:10.1002/qj.49711247307.

Collins W, Bellouin N, Doutriaux-Boucher M, Gedney N, Halloran P, Hinton T, Hughes J, Jones C, Joshi M, Liddicoat S, Martin G, O’Connor F, Rae J, Senior C, Sitch S, Totterdell I, Wiltshire A, Woodward S., 2011. Development and evaluation of an Earth-System model - HadGEM2. Geoscientific Model Dev. 4: 1051-1075. doi:10.5194/gmd-4-1051-2011.

Cuevas, E., 2013. Establishing a WMO Sand and Dust Storm Warning Advisory and Assessment System Regional Node for West Asia: Current Capabilities and Needs, WMO-No. 1121, Chair, Publications Board World Meteorological Organization (WMO), ISBN 978-92-63-11121-0, December 2013.

De Longueville, F., Hountondji, Y.-C., Henry, S., and Ozer, P., 2013. What do we know about effects of desert dust on air quality and human health in West Africa compared to other regions?, Science of The Total Environment, 409, 1-8, http://dx.doi.org/10.1016/j.scitotenv.2010.09.025.

Dee, D. P., Uppala, S. M., Simmons, A. J., Berrisford, P., Poli, P., Kobayashi, S., Andrae, U., Balmaseda, M. A., Balsamo, G., Bauer, P., Bechtold, P., Beljaars, A. C. M., van de Berg, L., Bidlot, J., Bormann, N., Delsol, C., Dragani, R., Fuentes, M., Geer, A. J., Haimberger, L., Healy, S. B., Hersbach, H., Hólm, E. V., Isaksen, L., Kållberg, P., Köhler, M., Matricardi, M., McNally, A. P., Monge-Sanz, B. M., Morcrette, J.-J., Park, B.-K., Peubey, C., de Rosnay, P., Tavolato, C., Thépaut, J.-N. and Vitart, F., 2011. The ERA - Interim reanalysis: Configuration and performance of the data assimilation system. Quarterly Journal of the Royal Meteorological Society, 137(656), 553-597. 
Díaz, J., Tobías, A., and Linares, C., 2012. Saharan dust and association between particulate matter and case-specific mortality: a case-crossover analysis in Madrid (Spain), Environ. Health, 11(11).

Elminir, H-K., A.E. Ghitas, R.H. Hamid, F. El-Hussainy, M.M. Beheary, K. M. Abdel-Moneim, 2006. Effect of dust on the transparent cover of solar collectors, Energy Conversion and Management, 47, 3192-3203.

El-Nashar A.M., 2003. Effect of dust deposition on the performance of a solar desalination plant operating in an arid desert area, Solar Energy, Vol. 75, Issue 5, 421-431.

Ferrier, B. S., Jin, Y., Lin, Y., Black, T., Rogers, E., and DiMego, G., 2002. Implementation of a new grid-scale cloud and precipitation scheme in the NCEP Eta Model, in: Proceedings of the $15^{\text {th }}$ Conference on Numerical Weather Prediction, 280-283.

Fung, I., Meyn, S. K., Tegen, I., Doney, S., John, J., and Bishop, J., 2000. Iron supply and demand in the upper ocean, Global Biogeochem. Cy., 14, 281-295.

Goudie, A. S., and Middleton, N. J., 2006. Desert Dust in the Global System, Springer Berlin Heidelberg.

Ginoux, P., Chin, M., Tegen, I., Prospero, J., Holben, B.N., Dubovik, O., and Lin, S.-J., 2001. Sources and distributions of dust aerosols simulated with the GOCART model. J Geophys Res106:20255-20274.

Ginoux, P., Prospero, J. M., Gill, T. E., Hsu, N. C., and Zhao, M. 2012. Global - scale attribution of anthropogenic and natural dust sources and their emission rates based on MODIS Deep Blue aerosol products. Reviews of Geophysics, 50(3).

Hamidi, M., Kavianpour, M. R., and Shao, Y., 2014. Numerical simulation of dust events in the Middle East. Aeolian Research, 13, 59-70.

Haustein, K., Pérez, C., Baldasano, J. M., Jorba, O., Basart, S., Miller, R. L., Janjic, Z., Black, T., Nickovic, S., Todd, M. C., Washington, R., Müller, D., Tesche, M., Weinzierl, B., Esselborn, M., and Schladitz, A., 2012. Atmospheric dust modeling from meso to global scales with the online NMMB/BSC-Dust model - Part 2: Experimental campaigns in Northern Africa, Atmos. Chem. Phys., 12, 2933-2958, doi:10.5194/acp-12-2933-2012.

Holben, B. N., Eck, T. F., Slutsker, I., Tanre, D., Buis, J. P., Setzer, A., Vermote, E., Reagan, J., Kaufman, Y., Nakajima, T., Lavenu, F., Jankowiak, I., and Smirnov, A., 1998. AERONET: A Federated Instrument Network and Data Archive for Aerosol Characterization, Rem. Sens. Environ., 66, 1-16.

Hsu, N. C., Tsay, S. C., King, M. D., and Herman, J. R., 2004. Aerosol properties over bright-reflecting source regions, IEEE T. Geosci. Remote, 42, 557-569.

Ignatov, A. and Gutman, G., 1998. The derivation of the green vegetation fraction from NOAA/AVHRR data for use in numerical weather prediction models, Int. J. Remote Sens., 19, 1533-1543, doi:10.1080/014311698215333, 1998.

IPCC, Intergovernmental Panel on Climate Change, 2014. Climate Change 2013: The Physical Science Basis. Cambridge University Press, Cambridge, United Kingdom. https://www.ipcc.ch/report/ar5/wg1/.

Israelevich, P., Ganor, E., Alpert, P., Kishcha, P., and Stupp, A. 2012. Predominant transport paths of Saharan dust over the Mediterranean Sea to Europe, J. Geophys. Res., 117.

Janjic, Z. I. and Black, T., 2007. A unified model approach from meso to global scales. Geophysical Research Abstracts, 7, SRef-ID: 1607-7962/gra/EGU2007-A-05 025.

Janjic, Z. I., Black, T., Pyle, M., Chuang, H.-Y., Rogers, E., and DiMego., E., 2005. High resolution applications of the WRF NMM. In Joint Session 16 (pages 1-21).

Janjic, Z. I., 1994. The step-mountain eta coordinate model: further developments of the convection, viscous sublayer, and turbulence closure schemes, Mon. Weather Rev., 122, 927-945.

Jickells, T. D., An, Z. S., Andersen, K. K., Baker, A. R., Bergametti, G., Brooks, N., Cao, J. J., Boyd, P. W., Duce, R. A., Hunter, K. A., Kawahata, H., Kubilay, N., la Roche, J., S., L. P., Mahowald, N., Prospero, J. M., Ridgwell, A. J., Tegen, I., and Torres, R., 2005. Global iron connections between desert dust, ocean biogeochemistry, and climate, Science, 308, 67-71.

Jickells, T., and Spokes, L., 2001. Atmospheric iron inputs to the oceans, in: Biogeochemistry of Iron in Seawater, edited by: Turner, D. R. and Hunteger, K., John Wiley and Sons, Ltd., Chichester, 85121.

Jorba, O., Dabdub, D., Blaszczak-Boxe, C., Pérez, C., Janjic, Z., Baldasano, J. M., Spada, M., Badia, A., and Gonçalves, M., 2012. Potential significance of photoexcited NO2 on global air quality with the NMMB/BSC chemical transport model, J. Geophys. Res., doi:10.1029/2012JD017730.

Karyampudi, V. M., and H.F. Pierce., 2002. Synoptic-scale influence of the Saharan air layer on tropical cyclogenesis over the Eastern Atlantic. Mon. Wea. Rev., 130, 3100-3128. 
Kazem, A.A., M.T. Chaichan, and H.A. Kazem., 2014. Dust effect on photovoltaic utilization in Iraq: Review article, Renewable and Sustainable Energy Reviews, 37, 734-749.

Levy, R.C., Remer, L.A., Kleidman, R.G., Mattoo, S., Ichoku, C., Kahn, R. and Eck, T.F., 2010. Global Evaluation of the Collection 5 MODIS Dark-Target Aerosol Products over Land. Atmos.Chem. Phys. 10:10399-10420.

Liu, M., and Westphal, D. L., 2001. A study of the sensitivity of simulated mineral dust production to model resolution, J. Geophys. Res., 106, 18099-18112.

Mahowald, N. M., Baker, A. R., Bergametti, G., Brooks, N., Duce, R. A., Jickells, T. D., Kubilay, N., Prospero, J. M., and Tegen, I., 2005. The atmospheric global dust cycle and iron inputs to the ocean, Global Biogeochemical Cycles, 19, doi: 10.1029/2004GB002402.

Mahowald, N., Kloster, S., Engelstaedter, S., Moore, J. K., Mukhopadhyay, S., McConnell, Albani, S., Doney, S., Bhattacharya, A., Curran, M., Flanner, M., Hoffman, F., Lawrence, D., Lindsay, K., Mayewski, P., Neff, J., Rothenberg, D., Thomas, E., Thornton, P., and Zender, C., , 2010. Observed 20th century desert dust variability: impact on climate and biogeochemistry, Atmospheric Chemistry and Physics, 10, 10875-10893.

Marticorena, B. and Bergametti, G., 1995. Modeling the atmospheric dust cycle: 1. Design of a soilderived dust emission scheme, J. Geophys. Res., 100, 16415-16430.

Marticorena, B., Bergametti, G., Aumont, B., Callot, Y., N'Doume, C., and Legrand, M., 1997. Modeling the atmospheric dust cycle: 2. Simulation of Saharan dust sources, J. Geophys. Res., $102,4387-4404$.

Menut, L., Pérez, C., Haustein,K., Bessagnet, B., Prigent, C., and Alfaro, S., 2013. Impact of surface roughness and soil texture on mineral dust emission fluxes modeling. J. Geophys. Res., 118, 6505-6520, doi:10.1002/jgrd.50313.

Menut, L., 2008. Sensitivity of hourly Saharan dust emissions to NCEP and ECMWF modeled wind speed, J. Geophys. Res. 113, D16201.

Merchant, C. J., Embury, O., Le Borgne, P., and Bellec, B., 2006. Saharan dust in night-time thermal imagery: detection and reduction of related biases in retrieved sea surface temperature, Remote Sensing of Environment, 104, 15-30.

Miller, R. L., Perlwitz, J., and Tegen, I., 2004. Modeling Arabian dust mobilization during the Asian summer monsoon: The effect of prescribed versus calculated SST, Geophys. Res. Lett., 31.

Mlawer, E. J., Taubman, S. J., Brown, P. D., Iacono, M. J., and Clough, S. A. 1997. Radiative transfer for inhomogeneous atmospheres: RRTM, a validated correlated-k model for the longwave, J. Geophys. Res., 102, 16663-16682, doi:10.1029/97JD00237.

Morcrette, J.-J., Boucher, O., Jones, L., Salmond, D., Bechtold, P., Beljaars,A., Benedetti, A., Bonet, A., Kaiser, J.W., Razinger, M., Schulz, M., Serrar, S., Simmons, A.J., Sofiev, M., Suttie, M., Tompkins, A.M., Untch A., 2009. Aerosol analysis and forecast in the ECMWF Integrated Forecast System. Part I: Forward modelling, J. Geophys. Res., 114, D06206, doi:10.1029/2008JD011235.

Nickovic, S., Kallos, G., Papadopoulos, A., and Kakaliagou, O., 2001. A model for prediction of desert dust cycle in the atmosphere, J. Geophys. Res., 106, 18113-18130, doi: 10.1029/2000JD900794.

Ohde, T., and H. Siegel., 2012. Impacts of Saharan dust and clouds on photosynthetically available radiation in the area off Northwest Africa, Tellus B, 64, 17160, DOI: 10.3402/tellusb.v64i0.17160.

Pérez García-Pando, C., Stanton, M.C., Diggle, P.J., Trzaska, S., Miller, R.L., Perlwitz, J.P., Baldasano, J.M., Cuevas, E., Ceccato, P., Yaka, P., and Thomson, M.C., 2014. Soil Dust Aerosols and Wind as Predictors of Seasonal Meningitis Incidence in Niger, Environmental Health Perspectives, doi:10.1289/ehp.1306640.

Pérez, C., Haustein, K., Janjic, Z., Jorba, O., Huneeus, N., Baldasano, J. M., Black, T., Basart, S., Nickovic, S., Miller, R. L., Perlwitz, J. P., Schulz, M., and Thomson, M., 2011. Atmospheric dust modeling from meso to global scales with the online NMMB/BSC-Dust model: 1. Model description, annual simulations and evaluation, Atmos. Chem. Phys., 11, 13001-13027, doi:10.5194/acp-11-13001-2011.

Pérez, C., Nickovic, S., Baldasano, J. M., Sicard, M., Rocadenbosch, F., and Cachorro, V. E., 2006a. A long Saharan dust event over the western Mediterranean: Lidar, Sun photometer observations, and regional dust modeling, J. Geophys. Res., 111, D15214, doi:10.1029/2005JD00657.

Pérez, C., Nickovic, S., Pejanovic, G., Baldasano, J. M., and Ozsoy, E., 2006b. Interactive dust-radiation modeling: A step to improve weather forecasts, J. Geophys. Res., 11, D16206, doi:10.1029/2005JD006717. 
Prakash, J. P., Stenchikov, G., Kalenderski, S., Osipov, S., and Bangalath, H., 2014. The impact of dust storms on the Arabian Peninsula and the Red Sea, Atmos. Chem. Phys. Discuss., 14, 19181 19245, doi:10.5194/acpd-14-19181-2014.

Prospero, J. M., Schmitt, R., Cuevas, E., Savoie, D. L., Graustein, W. C., Turekian, K. K., Volz-Thomas, A., DmHaz, A., Oltmans, S.J., and Levy II, H., 1995. Temporal variability of summer-time ozone and aerosols in the free troposphere over the eastern North Atlantic, Geophys. Res. Lett., $22,2925-2928$.

Prospero, J. M., Ginoux, P., Torres, O., Nicholson, S. E., and Gill, T. E., 2002. Environmental characterization of global sources of atmospheric soil dust identified with the nimbus 7 total ozone mapping spectrometer (TOMS) absorbing aerosol product, Rev. Geophys., 40(1), doi:10.1029/2000RG000095.

Prospero J. M. and Lamb P.J., 2003. African droughts and dust transport to the Caribbean: climate change implications. Science 302:1024-1027.

Remer, L. A., Kaufman, Y. J., Tanr’e, D., Mattoo, S., Chu, D. A., Martins, J. V., Li, R. R., Ichoku, C., Levy, R. C., Kleidman, R. G., Eck, T. F., Vermote, E., and Holben, B. N., 2005. The MODIS aerosol algorithm, products, and validation, J. Atmos. Sci., 62, 947-973.

Rezazadeh, M., Irannejad, P., and Shao, Y., 2013. Climatology of the Middle East dust events, Aeolian Research, 10, 103-109.

Schmechtig, C., Marticorena, B., Chatenet, B., Bergametti, G., Rajot, J. L., and Coman, A., 2011. Simulation of the mineral dust content over Western Africa from the event to the annual scale with the CHIMERE-DUST model, Atmos. Chem. Phys., 11, 7185-7207, doi:10.5194/acp-117185-2011.

Schulz, M., Prospero, J.M., Baker, A.R., Dentener, F., Ickes, L., Liss, P.S., Mahowald, N.M., Nickovic, S., Pérez, C., Rodríguez, S., Manmohan Sarin, M., Tegen, I., and Duce, R.A., 2012. The atmospheric transport and deposition of mineral dust to the ocean: Implications for research needs. Environ. Sci. Technol., 46, 10390-10404, doi:10.1021/es300073u.

Sessions, W. R., Reid, J. S., Benedetti, A., Colarco, P. R., da Silva, A., Lu, S., Sekiyama, T., Tanaka, T. Y., Baldasano, J. M., Basart, S., Brooks, M. E., Eck, T. F., Iredell, M., Hansen, J. A., Jorba, O. C., Juang, H.-M. H., Lynch, P., Morcrette, J.-J., Moorthi, S., Mulcahy, J., Pradhan, Y., Razinger, M., Sampson, C. B., Wang, J., and Westphal, D. L. 2015. Development towards a global operational aerosol consensus: basic climatological characteristics of the International Cooperative for Aerosol Prediction Multi-Model Ensemble (ICAP-MME). Atmos. Chem. Phys, $15,335-362$.

Shao, Y., 2008. Physics and Modelling of Wind Erosion. Springer, University of Cologne, Germany.

Shirkhani-Ardehjani, S., 2012. I.R of Iran National Report on Regional Action Plan to combat dust and sand storm, International Cooperative for Aerosol Prediction (ICAP) 4th Workshop: Aerosol Emission and Removal Processes, May 14 - 17, 2012, ESA/ESRIN, Frascati, Italy.

Smirnov, A., Holben, B. N., Eck, T. F., Dubovik, O., and Slutsker, I., 2000. Cloud screening and quality control algorithms for the AERONET database, Remote Sens. Environ., 73, 337-349.

Spada, M., Jorba, O., Pérez García-Pando, C., Janjic, Z., and Baldasano, J. M., 2013. Modeling and evaluation of the global sea-salt aerosol distribution: sensitivity to size-resolved and sea-surface temperature dependent emission schemes, Atmos. Chem. Phys., 13, 11735-11755.

Stefanski, R., and M.V.K. Sivakumar., 2009. Impacts of Sand and Dust Storms on Agriculture and Potential Agricultural Applications of a SDSWS, IOP Conf. Ser.: Earth Environ. Sci., 7, 012016 doi:10.1088/1755-1307/7/1/012016.

Sulaiman, S.A., H.H. Hussain, N. S. Nik Leh, and M.S. I. Razali. 2011., Effects of Dust on the Performance of PV Panels, World Academy of Science, Engineering and Technology, 58.

Tanaka, T. Y., and Chiba, M., 2006. A numerical study of the contributions of dust source regions to the global dust budgets, Global Planet. Change, 52 (1), 88-104.

Tegen, I., and Lacis, A. A., 1996. Modeling of particle size distribution and its influence on the radiative properties of mineral dust aerosol, 101, 19237-19244.

Tegen, I., P. Hollrig, M. Chin, I. Fung, D. Jacob, and J. Penner, 1997. Contribution of different aerosol species to the global aerosol extinction optical thickness: Estimates from model results. J. Geophys. Res., 102, 23895-23915, doi:10.1029/97JD01864.

Tegen, I., Harrison, S. P., Kohfeld, K., Prentice, I. C., Coe, M., and Heimann, M., 2002. Impact of vegetation and preferential source areas on global dust aerosol: Results from a model study, J. Geophys. Res., 107.

Terradellas, E., S. Basart, M. Schulz, J. M. Baldasano, J.-J.Morcrette, G. Pejanovic, L. Menut, A. Benedetti, O. Jorba, S. Nickovic and F. Benincasa. 2012. Intercomparison of dust prediction 
models in the framework of the WMO SDS-WAS programme, European Aerosol Conference, Granada, Spain.

Thomson, M. C., Molesworth, A. M., Djingarey, M. H., Yameogo, K. R., Belanger, F., and Cuevas, L. E., 2006. Potential of environmental models to predict meningitis epidemics in Africa, Tropical Medicine and International Health, 11, 781-788.

UNEP, 2012. United Nations Environment Programme. GEO5 Global Environment Outlook, Environment for the Future we want, Chapter 14: West Asia, ISBN: 978-92-807-3177-4, UNEP Job Number: DEW/1417/NA.

Westphal, D. L., Curtis, C. A., Liu, M., and Walker, A. L., 2009. Operational aerosol and dust storm forecasting, IOP Conf. Ser.: Earth Environ. Sci. 7, 012007.

White, B. R., 1979. Soil transport by winds on Mars, J. Geophys. Res., 84, 4643-4651.

Woodward S., 2011. Mineral dust in HadGEM2. Technical Report 87, Met Office Hadley Centre for Climate Change, Exeter, United Kingdom. http://www.metoffice.gov.uk/archive/science/climatescience/hctn87.

Zhang, L., Gong, S., Padro, J., and Barrie, L., 2001. A size-segregated particle dry deposition scheme for an atmospheric aerosol module, Atmos. Environ., 35, 549-560. 